\title{
INORGANIC NUTRITIONAL COMPOSITION OF COMMON BEAN (Phaseolus vulgaris L.) GENOTYPES RACE CHILE
}

\author{
Mario Paredes C. ${ }^{1 *}$, Viviana Becerra V. ${ }^{1}$, and Juan Tay U. ${ }^{1}$
}

\begin{abstract}
The current Chilean bean (Phaseolus vulgaris L.) collection is about 1110 accessions. To facilitate the characterization of this germplasm a core collection of 246 accessions was formed. Little information exists about the mineral content and other quality traits for those bean genotypes. This information could be useful to determine their quality and to promote its consumption. The objective of this work was to evaluate the variability for macro and micronutrients of a representative bean sample from a Chilean core collection and to compare them with representatives from other races. The results indicated the presence of a wide variability for some macro and micronutrients, such as $\mathrm{N}, \mathrm{Fe}$, and $\mathrm{Zn}$. The protein content varied from 183.5 to $259.7 \mathrm{~g} \mathrm{~kg}^{-1}$, Fe from 68.9 to $152.4 \mathrm{mg} \mathrm{kg}^{-1}$, and $\mathrm{Zn}$ from 27.9 to $40.7 \mathrm{mg} \mathrm{kg}^{-1}$. This situation could allow to select those genotypes with higher elements and to improve the current cultivars. The simple correlation analysis indicated that the $\mathrm{N}$ content was positively correlated with protein, $\mathrm{P}$, $\mathrm{Cu}, \mathrm{Zn}$, and $\mathrm{S}$ content and negatively correlated with $\mathrm{B}$ content and the $\mathrm{C} / \mathrm{N}$ ratio of the seed. The $\mathrm{Fe}$ content was positively correlated with $\mathrm{Mn}$ and $\mathrm{Ca}$ content and $\mathrm{Zn}$ content was positively correlated with the $\mathrm{N}, \mathrm{P}, \mathrm{Cu}$ and $\mathrm{S}$ content and negatively correlated with the relation $\mathrm{C} / \mathrm{N}$ ratio of bean seed. There were no significant differences between the Chilean bean genotypes compared to genotypes from other races.
\end{abstract}

Key words: Phaseolus vulgaris, race Chile, macronutrients, micronutrients, core collection.

\section{INTRODUCTION}

The common bean (Phaseolus vulgaris L.) constitutes a traditional food for many people in Latin America, Africa, and Asia (Messina, 1999). Dry bean is a good source of protein, essential vitamins and minerals, soluble-fiber starch, phytochemicals, and it is a low fat food (Meiners et al., 1976; Messina, 1999).

Beans could serve as functional food because contain a number of bioactive compounds such as enzyme inhibitors, lectins, phytates, oligosaccharides, and phenolic substances that may play metabolic roles in humans and animals that frequently consume this food (Díaz-Batalla et al., 2006). The consumption of beans has been associated to several health benefits like reduction of cholesterol level (Rosa et al., 1998), and coronary heart diseases (Anderson et al., 1999; Bazzano et al., 2001), favorable effects against cancer (Hangen and Bennink, 2002), decrease of diabetes and obesity (Geil and Anderson, 1994), high antioxidant capacity (Heimler et al., 2005), antimutagenic (Azevedo et al., 2003), and antiproliferative effects (Aparicio-Fernández et al., 2006).

${ }^{1}$ Instituto de Investigaciones Agropecuarias INIA, Casilla 426, Chillán, Chile. "Corresponding author (mparedes@inia.cl).

Received: 05 December 2008.

Accepted: 23 March 2009.
The genetic structure of common bean describes two main centers of diversity, one located in the Andes and another in the Mesoamerica region (Gepts and Debouck, 1991; Becerra-Velásquez and Gepts, 1994). These main centers recognize three main races, Mesoamerica, Durango, and Jalisco in the Mesoamerican gene pool, and race Chile, Nueva Granada, and Perú in the Andean gene pool (Singh et al., 1991a). Besides this classification, other reports proposed the existence of secondary gene pools (Beebe et al., 1997) and the new race Guatemala in Mesoamerica (Beebe et al., 2000b) that could explain better the genetic structure of the common bean.

The common bean germplasm collected in Chile has been classified as races Chile, Nueva Granada, Peru, Durango, and Mesoamerica, with the only exception to race Jalisco. This situation could be explained by commercial reasons and by the good adaptation of bean species to Chilean agro-climatic conditions. The current bean collection in Chile consists of 1110 accessions approximately. To facilitate its characterization a core collection was formed with 246 accessions representing the genetic variability found in the general collection (Paredes and Becerra, unpublished data).

Accessions from different gene pools have been classified based on their response and adaptation to the ecological conditions, also on their reaction to races of 
pathogens and other traits. For instance, the Middle American gene pool had higher lectin, $\mathrm{Ca}, \mathrm{P}, \mathrm{S}$ and $\mathrm{Zn}$ than the Andean gene pool, but lower phaseolin and $\mathrm{Fe}$ (Islam et al., 2002).

Bean consumers of different countries and regions, even within the countries, show specific preferences for various combinations of seed size, shape and color cooking time, broth appearance, and storability (ShellieDessert and Bliss, 1991). For example in Chile, the most accepted and consumed dry bean market classes are Tórtola and Coscorrón (Singh et al., 1991a; Paredes, 1994). In addition, other minor market classes such as Manteca, Sapito, and Cuyano, are also consumed in some specific rural areas.

Little information exists about most of the mineral content, cooking quality, contents of flavonoids, phenolic acids, total phenolics, tannins, and antioxidant capacity of common beans from race Chile, therefore, there is a need to characterize this germplasm in order to promote its consumption.

The objective of this work was to characterize a representative sample of bean genotypes from the bean core collection for its chemical composition and compare them with other genotypes for future genetic improvement.

\section{MATERIALS Y METHODS}

\section{Plant material}

Fifty representative genotypes of the bean core collection were utilized in this study. This sample consisted of 40 accessions previously classified as race Chile and two accessions representing race Nueva Granada, Peru, Durango, Mesoamerica, and genotypes not classified yet. These 10 genotypes representing other races were included for comparative purposes with race Chile (Table 1).

\section{Methods}

Fifty accessions were analyzed for $\mathrm{N}, \mathrm{P}, \mathrm{K}, \mathrm{Ca}, \mathrm{Mg}$, $\mathrm{Na}, \mathrm{Cu}, \mathrm{Fe}, \mathrm{Mn}, \mathrm{Zn}, \mathrm{B}, \mathrm{S}$, and $\mathrm{C}$. The $\mathrm{C}$ and $\mathrm{N}$ content was utilized to calculate the relation $\mathrm{C} / \mathrm{N}$ in the bean seed. Besides, the $\mathrm{N}$ content of the seed was multiplied by 6.25 to obtain the protein content (Guzmán-Maldonado et al., 2000).

Bean seed samples were ground to a fine powder to ensure homogeneity before analysis of macro and micronutrients. Seed bean N, S, and C were determined by the thermal conductivity procedure that included the combustion of the sample to $1040{ }^{\circ} \mathrm{C}$ (Sadzawka et al., 2007). The $P$ and $B$ concentrations were measured by colorimetric method using acidic vanadate molibdate, and azometrine-H, respectively (Sadzawka et al., 2007). Potassium, $\mathrm{Ca}, \mathrm{Mg}, \mathrm{Na}, \mathrm{Fe}, \mathrm{Mn}$, and $\mathrm{Zn}$ were determined by flame atomic absorption spectrometry (Perkin-Elmer spectrophotometer, model 1100B, Phoenix, Arizona, USA; Sadzawka et al., 2007). All these macro and micronutrient determinations included calcination of the seed sample to $500{ }^{\circ} \mathrm{C}$ and dissolution with $\mathrm{HCl}$ (Sadzawka et al., 2007).

\section{Statistical analysis}

All data were subjected to an ANOVA appropriate to a randomized complete block design in each location. A combined ANOVA was calculated in a split plot design, where locations were analyzed as main plot and the 50 genotypes as a subplot. The least significant difference (LSD) was used to compare the mean of the genotypes. The simple correlation method between macro, micronutrients and 100-seed weight was also calculated using the SAS program (SAS Institute, 2007).

\section{RESULTS AND DISCUSSION}

The quality of bean seed is determined by the protein content, amino acid composition, digestibility, and presence of anti-nutritional factors (Shellie-Dessert and Bliss, 1991), mineral content, cooking quality, concentration of phenolic compounds, like flavonoids, phenolic acids, total phenolics, tannins, which contribute to the antioxidant capacity.

Nitrogen and protein contents. Dry bean is considered a good source of $\mathrm{N}$ and protein. For example, a serving of bean (approximately $90 \mathrm{~g}$ or $1 / 2$ cup cooked beans) provides approximately 7 to $8 \mathrm{~g}$ protein or about $15 \%$ of the recommended dietary allowance for protein for a $70 \mathrm{~kg}$ adult (Messina, 1999).

Genetic variability for protein concentration and for its specific seed protein components has been identified within the bean germplasm pool. The protein content in dry beans ranges between $20 \%$ and $30 \%$ (Shellie-Dessert and Bliss, 1991).

Nitrogen content of seed bean from the Chilean core collection varied between 29.4 and $41.5 \mathrm{~g} \mathrm{~kg}^{-1}$ and its protein from 183.5 (accession 90347) to $259.7 \mathrm{~g} \mathrm{~kg}^{-1}$ (accession 90395). The main market classes consumed in Chile, Tórtola presented a protein content that varied between 222.4 (accession 64) and $232.2 \mathrm{~g} \mathrm{~kg}^{-1}$ (accession 244) and Coscorrón ranged from 230.8 (accession 36) to $231.1 \mathrm{~g} \mathrm{~kg}^{-1}$ (accession 31) (Table 2). On the average, the accessions from Perú, Nueva Granada, Mesoamerica and Durango did not show a significant difference with the genotypes from race Chile.

A study carried out on bean collected in Jalisco (Mexico) showed that the protein content ranged from 222 to $330 \mathrm{~g} \mathrm{~kg}^{-1}$, whereas those collected from Durango (Mexico) varied from 180 to $311 \mathrm{~g} \mathrm{~kg}^{-1}$ (Guzmán- 
Table 1. Bean genotypes analyzed for macro and microelements.

\begin{tabular}{|c|c|c|c|}
\hline Accession $\mathbf{N}^{\circ}$ & Common name & Race & 100-seed weight \\
\hline & & $\mathrm{g}$ & \\
\hline 15 & Avalito & Chile & 47.4 \\
\hline 31 & Coscorrón corriente & Chile & 53.7 \\
\hline 32 & Hallados & Chile & 51.5 \\
\hline 33 & Hallados Chico & Chile & 41.0 \\
\hline 36 & Coscorrón Méndez & Chile & 54.4 \\
\hline 41 & Sapito & Chile & 49.8 \\
\hline 52 & Azufrado & Chile & 39.4 \\
\hline 64 & Tórtola corriente & Chile & 59.3 \\
\hline 66 & Manteca & Chile & 46.5 \\
\hline 76 & Cara de niño & Chile & 57.6 \\
\hline 174 & María & Chile & 49.7 \\
\hline 243 & Juanita & Chile & 59.8 \\
\hline 244 & Treile & Chile & 49.9 \\
\hline 267 & Tórtola & Chile & 46.5 \\
\hline 286 & Frutilla & Chile & 52.9 \\
\hline 338 & Burro argentino & Chile & 37.9 \\
\hline 347 & Rancagüino & Chile & 60.5 \\
\hline 354 & Amarillo & Chile & 44.4 \\
\hline 476 & $\mathrm{NN}$ & Chile & 40.4 \\
\hline 567 & Peumo & Chile & 56.0 \\
\hline 90047 & $\mathrm{NN}$ & Chile & 35.9 \\
\hline 90094 & Bayo & Chile & 28.9 \\
\hline 90107 & Manteca & Chile & 36.8 \\
\hline 90116 & Jardín & Chile & 39.7 \\
\hline 90117 & Raucalmino & Chile & 40.9 \\
\hline 90118 & Azufrado & Chile & 32.4 \\
\hline 90261 & Caballero & Chile & 72.5 \\
\hline 90264 & Cabrito baya & Chile & 50.8 \\
\hline 90288 & Gato & Chile & 57.9 \\
\hline 90290 & Mono & Chile & 44.6 \\
\hline 90301 & Angelito & Chile & 44.9 \\
\hline 90303 & Sapito & Chile & 26.6 \\
\hline 90318 & NN & Chile & 43.9 \\
\hline 90347 & NN & Chile & 65.3 \\
\hline 90395 & NN & Chile & 60.6 \\
\hline 90418 & $\mathrm{NN}$ & Chile & 29.1 \\
\hline 90451 & Rayado & Chile & 39.6 \\
\hline 90463 & NN & Chile & 60.3 \\
\hline 90466 & $\mathrm{NN}$ & Chile & 46.4 \\
\hline 90469 & Sapo & Chile & 47.7 \\
\hline 90376 & $\mathrm{NN}$ & Peru & 44.2 \\
\hline 573 & Bayote & Peru & 57.9 \\
\hline 90212 & NN & Nueva Granada & 34.0 \\
\hline 313 & $\mathrm{NN}$ & Nueva Granada & 50.2 \\
\hline 90184 & $\mathrm{NN}$ & Durango & 32.4 \\
\hline 225 & NN & Durango & 34.3 \\
\hline 90209 & $\mathrm{NN}$ & Mesoamerica & 37.8 \\
\hline 233 & $\mathrm{NN}$ & Mesoamerica & 37.8 \\
\hline 90249 & Cabrito & $\mathrm{nc}$ & 63.5 \\
\hline 262 & NN & $\mathrm{nc}$ & 48.4 \\
\hline
\end{tabular}

NN: without common name; nc: non classified. 
Maldonado et al., 2000). These values agreed with those reported previously for cultivated dry common bean (Moraghan and Grafton, 1997; Guzmán-Maldonado et al., 2000; 2003). On the other hand, cultivated common bean presented on average lower protein content than wild and weedy bean samples collected in Jalisco and Durango (Guzmán-Maldonado et al., 2000).

Phosphorus, K, Ca, Mg, and Na contents. Genetic differences in seed mineral concentrations have been also detected among wild, weedy, and cultivated landraces and modern cultivars (Moraghan and Grafton, 1997; Graham et al., 1999; Beebe et al., 2000a; Guzmán-Maldonado et al., 2000; House et al., 2002; Gelin et al., 2007) and some of this variability has been exploited for the genetic improvement of the crop (Shellie-Dessert and Bliss, 1991; Singh et al., 1991b; Graham et al., 1999; Beebe et al., 2000a).

Calcium, $\mathrm{Mg}$ and $\mathrm{K}$ are the main cations present in common bean. Ca concentration is more variable than either $\mathrm{Mg}$ or $\mathrm{K}$ concentrations. Both environmental and genetic factors influence $\mathrm{Ca}$ accumulation in dry bean seed. The concentration of $\mathrm{Na}, \mathrm{Mg}$ and $\mathrm{Ca}$ in the seed is lower than that in other parts of the plant. This may be due to the mobility of these elements. The reverse situation occurs for $\mathrm{N}$ and $\mathrm{P}$ concentrations. However, $\mathrm{K}$ is distributed more uniformly throughout mature plants compared with $\mathrm{N}, \mathrm{P}, \mathrm{Ca}, \mathrm{Mg}$, and $\mathrm{Na}$ (Moraghan and Grafton, 1997).

In this study, the content of $\mathrm{P}, \mathrm{K}, \mathrm{Ca}, \mathrm{Mg}$ and $\mathrm{Na}$ varied slightly among genotypes. That is, the $\mathrm{P}$ content ranged from 4.0 to $5.6 \mathrm{~g} \mathrm{~kg}^{-1}$ and only one genotype (accession 90395 ) presented $5.6 \mathrm{~g} \mathrm{~kg}^{-1}$ and the rest of the genotypes were closer to $4 \mathrm{~g} \mathrm{~kg}^{-1}$. Potassium content varied between 14.2 to $18.4 \mathrm{~g} \mathrm{~kg}^{-1}$, Ca content were between 1.0 and 2.6 $\mathrm{g} \mathrm{kg}^{-1}$ and $\mathrm{Mg}$ content were between 1.3 and $2.3 \mathrm{~g} \mathrm{~kg}^{-1}$. Na content varied between 0.03 to $0.12 \mathrm{~g} \mathrm{~kg}^{-1}$ (Table 2).

The analysis of 1072 accessions from Core Collection of common bean of Centro Internacional de Agricultura Tropical (CIAT), Colombia, indicated that the mean of $\mathrm{P}$ content was $3.6 \mathrm{~g} \mathrm{~kg}^{-1}$ with a range from 2.2 to 7.1 $\mathrm{g} \mathrm{kg}^{-1}$, our data presented a lower genetic variability. In another study, carried out in a recombinant population of navy bean population the $\mathrm{P}$ and $\mathrm{Ca}$ content varied from 4.2 to $3.9 \mathrm{mg} \mathrm{kg}^{-1}$ of $\mathrm{P}$ and from 2.4 to $1.4 \mathrm{mg} \mathrm{kg}^{-1}$ of $\mathrm{Ca}$, considering the $10 \%$ top and bottom of the population (Gelin et al., 2007). Other data indicated that the mean of Ca content was $1.5 \mathrm{~g} \mathrm{~kg}^{-1}$ and varied from 0.5 to $3.1 \mathrm{~g}$ $\mathrm{kg}^{-1}$ (Islam et al., 2002). Differences in Ca concentration were also reported in different cultivated bean market classes. For instance, the average $\mathrm{Ca}$ concentration in six navy bean cultivars was $90 \%$ more than the mean of three kidney and three cranberry bean cultivars. In this situation, the higher $\mathrm{Ca}$ concentration did not result from greater $\mathrm{Ca}$ absorption, but in changes of the seed-coat area/cotyledon weight ratios with increasing seed size, therefore increased growth rates of pods in a large-seeded cultivars resulted in decreased $\mathrm{Ca}$ concentrations due to lack of mobility of $\mathrm{Ca}$ from vegetative tissue to fruiting structures (Moraghan and Grafton, 1997). The wild and weedy dry bean contained more $\mathrm{Ca}$ than in the cultivated genotypes (Guzmán-Maldonado et al., 2000).

Cupper, Fe, Mn, Zn, and $B$ contents. Among the micronutrients $\mathrm{Fe}$ and $\mathrm{Zn}$, vitamin $\mathrm{A}$, folate, and I (Sanghvi et al., 2007) have captured attention as being of public health concern, meanwhile other elements like Se and B deficiency and some vitamin like $\alpha$-tocopherol, ascorbate, cobalamin, and folate, are currently of growing concern to human nutrition (Graham et al., 2001).

In developing countries, cereal grains and some legumes are the primary and cheapest source of $\mathrm{Ca}$, $\mathrm{Fe}$ and $\mathrm{Zn}$, however, their intake does not satisfy the mineral requirements of the population in these countries (Guzman-Maldonado et al., 2000). In the last decade, poor health, lower worker productivity, high rate of mortality and morbidity, increasing rates of chronic diseases (coronary heart disease, cancer, stroke, and diabetes) and permanent impairment of cognitive abilities of infant born from micronutrient deficient mother have been related to poor micronutrient nutrition (Welch and Graham, 2000; Graham et al., 2001; Sanghvi et al., 2007).

Iron deficiency is the common nutrition disorder worldwide and affects a large proportion of women and children in developing countries. Indeed, an estimated 3.5 to 5 billion people are $\mathrm{Fe}$ deficient in the world (Underwood, 2000; Graham et al., 2001). Diets deficient in Fe are often $\mathrm{Zn}$ deficient (Monsen, 1988). The main symptoms of Zn deficiency include pregnancy complications, low birth weight, maternal and infant mortality and reduction of growth in infancy and childhood (Frossard et al., 2000). On the other hand, Ca deficiency has also been epidemiologically linked to several chronic diseases, including osteoporosis, hypertension, and colon cancer.

The analysis of this data indicated that the bean genotypes race Chile presented significant differences between them for all micronutrients evaluated (Table 3). The mean of $\mathrm{Cu}$ content was $10.9 \mathrm{mg} \mathrm{kg}^{-1}$ and varied from 8.8 to $12.8 \mathrm{mg} \mathrm{kg}^{-1}$. The mean of the Fe content was 90.2 $\mathrm{mg} \mathrm{kg}^{-1}$ with a range from 68.9 and $152.4 \mathrm{mg} \mathrm{kg}^{-1}$. On other hand, the Mn content varied from 9.6 to $18.9 \mathrm{mg} \mathrm{kg}^{-1}$. The $\mathrm{Zn}$ content ranged from 27.9 to $40.7 \mathrm{mg} \mathrm{kg}^{-1}$ and $\mathrm{B}$ from 9.3 to $15.3 \mathrm{mg} \mathrm{kg}^{-1}$. The $\mathrm{S}$ content varied from 2.2 to 2.8 $\mathrm{g} \mathrm{kg}^{-1}$ and the $\mathrm{C}$ between 410.9 to $425.3 \mathrm{~g} \mathrm{~kg}^{-1}$ and the relation $\mathrm{C} / \mathrm{N}$ from 10.2 to 14.4 (Table 3 ). 
Table 2. Average macronutrient content of grain dry beans at two locations, INIA La Platina (Santiago) and INIA Quilamapu (Chillán).

\begin{tabular}{|c|c|c|c|c|c|c|c|c|c|}
\hline $\begin{array}{l}\text { Accession } \\
\mathbf{N}^{\circ} \\
\end{array}$ & $\begin{array}{c}\text { Common } \\
\text { name }\end{array}$ & Race & $\mathbf{N}$ & Protein* & $\mathbf{P}$ & $\mathbf{K}$ & $\mathrm{Ca}$ & Mg & $\mathbf{N a}$ \\
\hline & & & & & & $\mathrm{g} \mathrm{kg}^{-1}$ & & & \\
\hline & Avalito & $\begin{array}{l}\text { Chile } \\
\text { Chile }\end{array}$ & $\begin{array}{l}31.5 \\
37.0\end{array}$ & $\begin{array}{l}197.5 \\
2311\end{array}$ & $\begin{array}{l}4.0 \\
4.9\end{array}$ & $\begin{array}{l}15.0 \\
15.9\end{array}$ & $\begin{array}{l}2.1 \\
17\end{array}$ & $\begin{array}{l}1.5 \\
1.7\end{array}$ & $\begin{array}{l}0.05 \\
0.11\end{array}$ \\
\hline $\begin{array}{l}31 \\
32\end{array}$ & $\begin{array}{l}\text { Coscorrón corriente } \\
\text { Hallados }\end{array}$ & $\begin{array}{l}\text { Chile } \\
\text { Chile }\end{array}$ & $\begin{array}{l}37.0 \\
37.8\end{array}$ & $\begin{array}{l}231.1 \\
236.4\end{array}$ & 4.9 & $\begin{array}{l}15.9 \\
16.9\end{array}$ & $\begin{array}{l}1.1 \\
2.0\end{array}$ & $\begin{array}{l}1.1 \\
1.7\end{array}$ & $\begin{array}{l}0.11 \\
0.12\end{array}$ \\
\hline 33 & Hallados Chico & Chile & 34.2 & 216.6 & 4.4 & 16.1 & 1.8 & 1.7 & 0.07 \\
\hline 36 & Coscorrón Méndez & Chile & 36.6 & 230.8 & 4.7 & 16.7 & 2.0 & 1.8 & 0.03 \\
\hline 41 & Sapito & Chile & 37.0 & 235.8 & 4.8 & 16.9 & 1.8 & 1.7 & 0.09 \\
\hline 52 & Azufrado & Chile & 34.8 & 217.4 & 4.9 & 16.3 & 1.6 & 1.6 & 0.08 \\
\hline 64 & Tórtola Corriente & Chile & 34.5 & 222.4 & 4.5 & 18.1 & 1.4 & 1.5 & 0.09 \\
\hline 66 & Manteca & Chile & 34.6 & 218.8 & 5.0 & 16.9 & 1.6 & 1.6 & 0.12 \\
\hline 76 & Cara de niño & Chile & 36.4 & 227.9 & 4.9 & 16.3 & 1.6 & 1.5 & 0.08 \\
\hline 174 & María & Chile & 36.2 & 226.0 & 4.7 & 16.2 & 1.8 & 1.5 & 0.07 \\
\hline 233 & Juanita & Chile & 36.4 & 232.4 & 4.9 & 16.5 & 1.8 & 1.4 & 0.07 \\
\hline 243 & Treile & Chile & 38.9 & 243.0 & 5.4 & 16.4 & 1.7 & 1.5 & 0.05 \\
\hline 244 & Tórtola & Chile & 37.1 & 232.2 & 5.0 & 17.9 & 1.8 & 1.7 & 0.08 \\
\hline 262 & Frutilla & Chile & 36.8 & 232.5 & 4.7 & 17.2 & 2.1 & 1.7 & 0.08 \\
\hline 267 & Burro Argentino & Chile & 36.6 & 231.3 & 4.9 & 16.8 & 1.0 & 1.5 & 0.10 \\
\hline 286 & Rancagüino & Chile & 34.2 & 213.6 & 4.6 & 15.3 & 2.0 & 1.6 & 0.08 \\
\hline 338 & Amarillo & Chile & 36.9 & 230.3 & 5.1 & 17.3 & 1.5 & 1.8 & 0.10 \\
\hline 347 & $\mathrm{NN}$ & Chile & 34.7 & 219.6 & 4.6 & 17.0 & 1.9 & 1.6 & 0.10 \\
\hline 354 & Peumo & Chile & 40.5 & 253.0 & 5.1 & 16.5 & 1.4 & 1.6 & 0.08 \\
\hline 90047 & $\mathrm{NN}$ & Chile & 37.9 & 236.8 & 5.1 & 17.3 & 1.8 & 1.6 & 0.10 \\
\hline 90094 & Bayo & Chile & 37.7 & 236.5 & 4.9 & 15.9 & 2.1 & 1.5 & 0.05 \\
\hline 90107 & Manteca & Chile & 39.5 & 246.8 & 5.1 & 14.7 & 1.6 & 1.3 & 0.09 \\
\hline 90116 & Jardín & Chile & 29.7 & 185.4 & 4.3 & 16.2 & 1.2 & 1.6 & 0.06 \\
\hline 90117 & Raucalmino & Chile & 36.1 & 225.9 & 5.0 & 18.4 & 1.2 & 1.5 & 0.06 \\
\hline 90118 & Azufrado & Chile & 40.1 & 250.3 & 5.0 & 15.8 & 1.0 & 1.6 & 0.08 \\
\hline 90261 & Caballero & Chile & 37.8 & 236.4 & 4.6 & 16.7 & 1.7 & 1.7 & 0.08 \\
\hline 90264 & Cabrito baya & Chile & 36.6 & 228.6 & 4.5 & 15.2 & 1.5 & 1.5 & 0.06 \\
\hline 90288 & Gato & Chile & 35.3 & 220.8 & 4.3 & 16.1 & 1.5 & 1.7 & 0.04 \\
\hline 90290 & Mono & Chile & 34.7 & 216.9 & 4.5 & 15.7 & 1.1 & 1.5 & 0.09 \\
\hline 90301 & Angelito & Chile & 36.2 & 226.4 & 4.6 & 15.6 & 1.9 & 1.7 & 0.05 \\
\hline 90303 & Sapito & Chile & 36.7 & 229.1 & 4.6 & 15.7 & 1.9 & 1.6 & 0.06 \\
\hline 90318 & $\mathrm{NN}$ & Chile & 34.3 & 214.4 & 4.4 & 15.2 & 1.7 & 1.5 & 0.06 \\
\hline 90347 & $\mathrm{NN}$ & Chile & 29.4 & 183.5 & 4.1 & 14.7 & 1.7 & 1.5 & 0.08 \\
\hline 90395 & $\mathrm{NN}$ & Chile & 41.5 & 259.7 & 5.6 & 14.2 & 1.3 & 1.4 & 0.06 \\
\hline 90418 & $\mathrm{NN}$ & Chile & 35.7 & 223.0 & 4.8 & 17.2 & 1.5 & 1.8 & 0.06 \\
\hline 90451 & Rayado & Chile & 39.5 & 246.8 & 5.1 & 16.4 & 1.5 & 1.5 & 0.06 \\
\hline 90463 & NN & Chile & 39.1 & 244.4 & 4.5 & 15.6 & 1.7 & 1.5 & 0.08 \\
\hline 90466 & $\mathrm{NN}$ & Chile & 40.1 & 259.8 & 4.9 & 15.0 & 1.9 & 1.6 & 0.06 \\
\hline 90469 & Sapo & Chile & 38.1 & 243.6 & 4.7 & 16.4 & 1.7 & 1.7 & 0.09 \\
\hline 90376 & NN & Peru & 39.0 & 245.4 & 5.3 & 16.2 & 1.8 & 1.5 & 0.06 \\
\hline 567 & Ballote & Peru & 33.5 & 209.2 & 4.6 & 15.6 & 1.7 & 1.5 & 0.08 \\
\hline 90212 & NN & N. Granada & 30.5 & 190.6 & 4.6 & 16.9 & 2.6 & 1.9 & 0.10 \\
\hline 476 & $\mathrm{NN}$ & N. Granada & 34.5 & 220.8 & 4.6 & 15.4 & 1.6 & 1.6 & 0.06 \\
\hline 573 & NN & Durango & 34.2 & 216.1 & 4.3 & 16.6 & 1.4 & 1.6 & 0.05 \\
\hline 90184 & NN & Durango & 37.9 & 237.2 & 4.9 & 16.0 & 1.7 & 1.5 & 0.05 \\
\hline 90209 & $\mathrm{NN}$ & Mesoamerica & 37.6 & 233.0 & 4.9 & 16.1 & 1.6 & 1.5 & 0.04 \\
\hline 313 & NN & Mesoamerica & 37.9 & 237.1 & 4.9 & 16.4 & 2.3 & 1.7 & 0.07 \\
\hline 90249 & Cabrito & $\mathrm{nc}$ & 36.7 & 229.4 & 4.5 & 16.5 & 1.5 & 1.6 & 0.07 \\
\hline 225 & $\mathrm{NN}$ & $\mathrm{nc}$ & 34.5 & 215.7 & 5.0 & 16.6 & 1.8 & 1.6 & 0.07 \\
\hline \multicolumn{3}{|c|}{ LSD at $5 \%$} & 3.2 & & 0.4 & 1.3 & 0.3 & 0.1 & 0.06 \\
\hline
\end{tabular}

NN: without common name; nc: non classified; LSD: least significant difference; N: Granada: Nueva Granada. 
Table 3. Average micronutrient content of dry bean grains at two locations, INIA La Platina (Santiago) and INIA Quilamapu (Chillán).

\begin{tabular}{|c|c|c|c|c|c|c|c|c|c|c|}
\hline $\begin{array}{l}\text { Accession } \\
\mathbf{N}^{\circ}\end{array}$ & $\begin{array}{c}\text { Common } \\
\text { name }\end{array}$ & Race & $\mathrm{Cu}$ & $\mathbf{F e}$ & Mn & Zn & B & $\mathbf{S}$ & C & $\mathrm{C} / \mathbf{N}$ \\
\hline & & & & & $\mathrm{mg} \mathrm{kg}^{-1}$ & & - & \multicolumn{2}{|c|}{$\left\lceil\mathrm{g} \mathrm{kg}^{-1}-\right.$} & \\
\hline 15 & Avalito & Chile & 9.8 & 69.5 & 13.3 & 35.0 & 11.9 & 2.2 & 418.7 & 13.3 \\
\hline 31 & Coscorrón corriente & Chile & 11.9 & 83.2 & 12.8 & 35.0 & 11.7 & 2.7 & 421.3 & 11.4 \\
\hline 32 & Hallados & Chile & 12.1 & 90.1 & 13.8 & 38.7 & 13.3 & 2.7 & 420.2 & 11.1 \\
\hline 33 & Hallados Chico & Chile & 10.4 & 80.8 & 12.4 & 33.3 & 12.6 & 2.6 & 419.1 & 12.3 \\
\hline 36 & Coscorrón Méndez & Chile & 11.4 & 101.9 & 13.5 & 35.9 & 11.7 & 2.6 & 418.7 & 11.4 \\
\hline 41 & Sapito & Chile & 12.4 & 92.0 & 14.5 & 34.6 & 12.4 & 2.7 & 421.2 & 11.4 \\
\hline 52 & Azufrado & Chile & 11.1 & 72.3 & 12.7 & 30.9 & 12.0 & 2.7 & 418.7 & 12.0 \\
\hline 64 & Tórtola corriente & Chile & 11.5 & 114.7 & 12.9 & 36.4 & 12.4 & 2.5 & 410.9 & 11.9 \\
\hline 66 & Manteca & Chile & 11.5 & 86.4 & 12.1 & 37.0 & 13.1 & 2.7 & 418.3 & 12.01 \\
\hline 76 & Cara de niño & Chile & 12.1 & 76.5 & 12.0 & 34.0 & 13.0 & 2.7 & 422.4 & 11.6 \\
\hline 174 & María & Chile & 11.4 & 96.9 & 14.4 & 32.1 & 12.4 & 2.6 & 422.0 & 11.7 \\
\hline 233 & Juanita & Chile & 9.6 & 81.1 & 12.4 & 31.4 & 10.8 & 2.7 & 418.5 & 11.5 \\
\hline 243 & Treile & Chile & 11.4 & 92.2 & 13.0 & 33.1 & 9.3 & 2.6 & 419.7 & 10.8 \\
\hline 244 & Tórtola & Chile & 11.8 & 100.2 & 14.7 & 35.9 & 12.1 & 2.7 & 412.9 & 11.1 \\
\hline 262 & Frutilla & Chile & 11.5 & 99.8 & 14.4 & 35.9 & 12.3 & 2.6 & 416.3 & 11.3 \\
\hline 267 & Burro Argentino & Chile & 10.8 & 80.1 & 11.1 & 33.1 & 11.0 & 2.7 & 414.9 & 11.3 \\
\hline 286 & Rancaguino & Chile & 10.0 & 82.6 & 13.0 & 30.8 & 11.6 & 2.4 & 418.0 & 12.2 \\
\hline 338 & Amarillo & Chile & 10.8 & 77.1 & 12.0 & 34.8 & 11.5 & 2.6 & 418.0 & 11.3 \\
\hline 347 & NN & Chile & 9.9 & 80.2 & 13.2 & 31.0 & 14.0 & 2.4 & 416.5 & 12.0 \\
\hline 354 & Peumo & Chile & 11.1 & 79.1 & 11.5 & 32.9 & 12.0 & 2.7 & 421.9 & 10.4 \\
\hline 90047 & NN & Chile & 10.2 & 103.1 & 13.3 & 34.1 & 12.5 & 2.7 & 417.3 & 11.0 \\
\hline 90094 & Bауо & Chile & 9.5 & 97.5 & 12.4 & 31.8 & 12.4 & 2.6 & 416.3 & 11.0 \\
\hline 90107 & Manteca & Chile & 9.8 & 102.6 & 13.6 & 32.4 & 10.5 & 2.8 & 418.8 & 10.6 \\
\hline 90116 & Jardín & Chile & 10.0 & 72.4 & 9.6 & 30.0 & 12.7 & 2.3 & 417.0 & 14.0 \\
\hline 90117 & Raucalmino & Chile & 10.5 & 91.7 & 11.1 & 31.5 & 12.2 & 2.6 & 417.2 & 11.5 \\
\hline 90118 & Azufrado & Chile & 11.6 & 86.3 & 12.7 & 34.3 & 11.3 & 2.7 & 417.1 & 10.4 \\
\hline 90261 & Caballero & Chile & 12.0 & 96.6 & 13.3 & 33.8 & 13.3 & 2.7 & 417.1 & 11.0 \\
\hline 90264 & Cabrito baya & Chile & 11.8 & 70.6 & 11.3 & 30.9 & 13.6 & 2.7 & 417.6 & 11.4 \\
\hline 90288 & Gato & Chile & 9.6 & 83.5 & 12.4 & 32.5 & 12.8 & 2.4 & 413.3 & 11.7 \\
\hline 90290 & Mono & Chile & 12.1 & 152.4 & 13.9 & 33.5 & 13.1 & 2.5 & 415.5 & 12.0 \\
\hline 90301 & Angelito & Chile & 11.3 & 101.6 & 13.9 & 32.9 & 14.0 & 2.6 & 421.3 & 11.6 \\
\hline 90303 & Sapito & Chile & 12.1 & 84.9 & 18.9 & 30.1 & 11.6 & 2.5 & 422.1 & 11.5 \\
\hline 90318 & NN & Chile & 9.9 & 75.1 & 12.5 & 31.2 & 13.6 & 2.4 & 420.1 & 12.2 \\
\hline 90347 & $\mathrm{NN}$ & Chile & 9.6 & 68.9 & 13.1 & 30.6 & 13.9 & 2.4 & 422.8 & 14.4 \\
\hline 90395 & $\mathrm{NN}$ & Chile & 12.8 & 82.0 & 12.9 & 33.1 & 13.2 & 2.8 & 425.3 & 10.2 \\
\hline 90418 & $\mathrm{NN}$ & Chile & 11.8 & 73.9 & 12.5 & 34.7 & 15.1 & 2.6 & 420.8 & 11.8 \\
\hline 90451 & Rayado & Chile & 10.7 & 92.0 & 11.9 & 37.6 & 12.8 & 2.7 & 421.2 & 10.7 \\
\hline 90463 & NN & Chile & 10.8 & 85.8 & 13.1 & 35.1 & 11.4 & 2.6 & 419.4 & 10.7 \\
\hline 90466 & $\mathrm{NN}$ & Chile & 10.8 & 99.4 & 13.0 & 37.4 & 11.1 & 2.8 & 419.4 & 10.5 \\
\hline 90469 & Sapo & Chile & 10.9 & 81.9 & 12.4 & 35.4 & 11.3 & 2.7 & 421.5 & 11.1 \\
\hline 90376 & NN & Peru & 11.0 & 97.7 & 12.8 & 40.7 & 12.0 & 2.8 & 419.4 & 10.8 \\
\hline 567 & Ballote & Peru & 9.2 & 104.6 & 15.1 & 29.9 & 10.7 & 2.5 & 415.9 & 12.4 \\
\hline 90212 & $\mathrm{NN}$ & NG & 10.6 & 78.5 & 15.1 & 32.4 & 15.3 & 2.2 & 419.6 & 13.8 \\
\hline 476 & $\mathrm{NN}$ & NG & 10.7 & 99.0 & 12.9 & 31.0 & 11.5 & 2.6 & 418.7 & 12.1 \\
\hline 573 & NN & Durango & 11.6 & 88.5 & 11.3 & 31.1 & 12.7 & 2.6 & 417.3 & 12.2 \\
\hline 90184 & NN & Durango & 8.8 & 100.5 & 12.7 & 27.9 & 12.9 & 2.6 & 420.7 & 11.1 \\
\hline 90209 & NN & Mesoam. & 11.4 & 110.2 & 13.1 & 31.9 & 13.0 & 2.7 & 424.4 & 11.3 \\
\hline 313 & NN & Mesoam. & 11.8 & 108.1 & 14.9 & 37.3 & 11.6 & 2.6 & 415.1 & 11.0 \\
\hline 90249 & Cabrito & $\mathrm{nc}$ & 11.5 & 87.3 & 12.6 & 32.3 & 12.3 & 2.5 & 419.0 & 11.4 \\
\hline 225 & NN & $\mathrm{nc}$ & 9.7 & 105.7 & 14.5 & 29.6 & 11.6 & 2.4 & 415.3 & 12.0 \\
\hline LSD & & & 2.19 & 44.55 & 3.29 & 5.06 & 1.40 & 0.2 & 10.9 & 0.98 \\
\hline
\end{tabular}




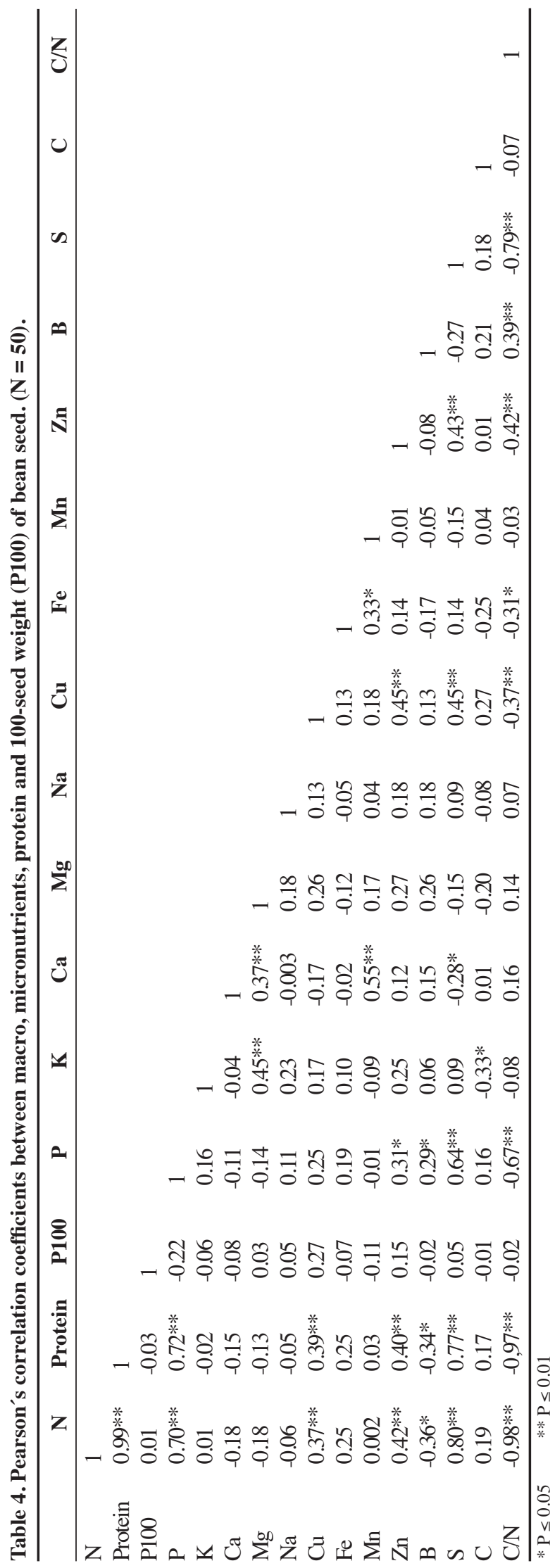

In an evaluation of more than thousand genotypes in the bean core collection of CIAT, the mean for $\mathrm{Cu}(18$ $\left.\mathrm{mg} \mathrm{kg}^{-1}\right), \mathrm{Fe}\left(60 \mathrm{mg} \mathrm{kg}^{-1}\right), \mathrm{Mn}\left(23 \mathrm{mg} \mathrm{kg}^{-1}\right), \mathrm{Zn}(29 \mathrm{mg}$ $\left.\mathrm{kg}^{-1}\right)$ and $\mathrm{S}\left(234 \mathrm{mg} \mathrm{kg}^{-1}\right)$ concentration were higher for wild beans $(\mathrm{n}=119)$ compared with the cultivated ( $\mathrm{n}$ $=1031)$ genotypes, that is, for Fe $\left(55 \mathrm{mg} \mathrm{kg}^{-1}\right), \mathrm{Mn}(15$ $\left.\mathrm{mg} \mathrm{kg}^{-1}\right)$, Zn (35 $\left.\mathrm{mg} \mathrm{kg}^{-1}\right)$ and $\mathrm{S}\left(2120 \mathrm{mg} \mathrm{kg}^{-1}\right)$ (Beebe et al., 2000a). A study of recombinant inbreed navy bean population showed that the $\mathrm{Zn}$ content varied from 32.3 to $17.5 \mathrm{mg} \mathrm{kg}^{-1}$ and the Fe content from 86.9 to $63.5 \mathrm{mg} \mathrm{kg}^{-1}$, calculated from the $10 \%$ top and bottom of the population (Islam et al., 2002).

Recent studies in bean have shown considerable variation among wild beans and modern cultivars, but domestication has not changed the mean concentration of $\mathrm{Fe}$ and $\mathrm{Zn}$ in seeds (Graham et al., 2001). The data collected suggest that there is sufficient genetic variability to increase about $80 \%$ and $50 \%$ of $\mathrm{Fe}$ and $\mathrm{Zn}$ content in the seed, respectively, and these genetic improvements will be stable across bean-growing environments (Welch and Graham, 2004).

The Andean and Mesoamerican gene pool differed significantly in almost all grain constituents. The Middle American gene pool presented higher concentrations for $\mathrm{Ca}, \mathrm{P}, \mathrm{S}$, and $\mathrm{Zn}$ with exception of Fe. Another study carried out on genotypes collected from North Andean Gene pool (Islam et al., 2002) and from introgressed genotypes (Islam et al., 2004) presented significantly higher $\mathrm{Fe}$ concentration than the two major gene pools. These studies also reported significant differences between introgressed and non introgressed common bean genotypes for protein, $\mathrm{Ca}, \mathrm{P}, \mathrm{S}, \mathrm{Fe}$, and Zn content (Islam et al., 2004). Besides, wild and weedy dry bean contain more $\mathrm{Zn}$ and $\mathrm{Fe}$ than the cultivated genotypes (Guzmán-Maldonado et al., 2000). This fact suggests that unique alleles might exist in this germplasm for several important nutrients.

Correlation analysis. The Pearson correlation analysis on the mean of 50 bean genotypes indicated that the protein and $\mathrm{N}$ content was positively correlated with the $\mathrm{P}, \mathrm{Cu}, \mathrm{Zn}$, and $\mathrm{S}$ content and negatively correlated with $\mathrm{B}$ content and the relation $\mathrm{C} / \mathrm{N}$. The $\mathrm{P}$ content was positively correlated with the content of $\mathrm{Zn}, \mathrm{B}$ and $\mathrm{S}$ in the seed and negatively correlated with the relation $\mathrm{C} / \mathrm{N}$. The $\mathrm{K}$ content was positively correlated with the $\mathrm{Mg}$ content and negatively correlated with the $\mathrm{C}$ content. The $\mathrm{Cu}$ content was positively correlated with the $\mathrm{Zn}$ and $\mathrm{S}$ content and negatively correlated with the relation $\mathrm{C} / \mathrm{N}$. The Fe content was positively correlated with $\mathrm{Mn}$ and negatively correlated with the relation $\mathrm{C} / \mathrm{N}$. The $\mathrm{Zn}$ content was positively correlated with $\mathrm{S}$ content and negatively correlated with the relation $\mathrm{C} / \mathrm{N}$ of the seed and finally the $\mathrm{B}$ and $\mathrm{C}$ content were correlated positively and negatively 
with the relationship $\mathrm{C} / \mathrm{N}$ of the bean seed, respectively (Table 4). One study showed that the $\mathrm{Zn}$ content of bean seed was positively correlated with $\mathrm{Fe}, \mathrm{Ca}, \mathrm{P}$ and yield but the highest correlation was found between $\mathrm{Fe}$ and $\mathrm{P}$ (Gelin et al., 2007). Similar correlations have been found between $\mathrm{Zn}$ and Ca (Guzmán Maldonado et al., 2003) and between $\mathrm{Zn}$ and $\mathrm{Fe}$ (House et al., 2002; Pfeiffer and McClafferty, 2007).

In the last decade, several Agricultural Research Centers started programs to explore the potential to improve the micronutrient quality of some staple food crops, including common bean (Graham et al., 1999; Welch and Graham, 2004; Pfeiffer and McClafferty, 2007). During 2003, the Consultative Group on International Agricultural Research (CGIAR) established HarvestPlus: The Biofortification Challenge Program. Biofortification is a new approach that relies on conventional plant breeding and modern biotechnology to increase the micronutrient density on the staple crops for improving the nutritional status and health of poor populations in both the rural and urban areas (Nestel et al., 2006; Pfeiffer and McClafferty, 2007).

To assess the feasibility to improve the mineral content of cultivated dry bean some studies have been carried out to identify quantitative trait loci (QTL) associated to Ca, $\mathrm{Fe}$ and $\mathrm{Zn}$ in crosses between cultivated and wild types (Guzmán-Maldonado et al., 2003). Other studies have reported the presence of bean microsatellites associated with Zn,P, and Ca (Gelin et al., 2007). As more information became available, breeders will be able to combine techniques of molecular genetics with conventional breeding methods through marker-assisted selection to develop cultivars with higher nutrients (Gelin et al., 2007) and other biotechnology tools (Bouis, 2002; Khush, 2002; Ghandilyan et al., 2006). Other strategy to increase the quality of bean seed could be the use of adequate methods to increase the nutritive value through the enhancement of the bioavailability of the micronutrients (Hotz and Gibson, 2007) and the reduction of the anti-nutritional substances present in the seed (Bressani, 2000; Graham et al., 2001; Welch and Graham, 2004; Ghandilyan et al., 2006).

\section{CONCLUSIONS}

The bean samples analyzed presented a wide variability for the macro and micro nutrient evaluated.

Bean genotypes of race Chile has a good level of protein, $\mathrm{Fe}$ and $\mathrm{Zn}$ and did not show significant differences with the genotypes from other races.

The simple correlation analysis indicated that $\mathrm{N}$ content was positively correlated with protein $\mathrm{P}, \mathrm{Cu}, \mathrm{Zn}$, and $\mathrm{S}$ content and negatively correlated with $\mathrm{B}$ content and seed $\mathrm{C} / \mathrm{N}$ relation.

The Fe content was positively correlated with $\mathrm{Mn}$ and $\mathrm{Ca}$ content, and $\mathrm{Zn}$ content was positively correlated with $\mathrm{N}, \mathrm{P}, \mathrm{Cu}$ and $\mathrm{S}$ content and negatively correlated with the $\mathrm{C} / \mathrm{N}$ relation.

There were no significant differences between the Chilean bean genotypes compared to genotypes from other races

\section{ACKNOWLEDGEMENTS}

The authors thank the Chilean Science and Technology Fund,FONDECYT (Project $N^{\circ}$ 1060185) for supporting this research and to Mr. Alfonso Valenzuela (INIA Quilamapu) and Mr. Pablo Gamboa (INIA La Platina) for their support on field trials, and Mr. Hugo Flores (INIA La Platina) for his support on the statistical analysis of the data.

\section{RESUMEN}

Composición inorgánica de semillas de genotipos de poroto (Phaseolus vulgaris L.), raza Chile. La colección de poroto común (Phaseolus vulgaris L.) en Chile cuenta con 1110 accesiones. Para facilitar la caracterización de este germoplasma se formó una colección núcleo de 246 accesiones. Existe poca información acerca del contenido de minerales y otras características de calidad para estos genotipos de poroto. Esta información podría ser útil para determinar la calidad y potencialidad de esta especie y para promover su consumo. El objetivo de este trabajo fue evaluar la variabilidad de los macro y micronutrientes de una muestra representativa de la colección núcleo y compararla con genotipos representativos de las otras razas. Los resultados indicaron la presencia de una amplia variabilidad de macro y micronutrientes, tales como N, Fe, y Zn. El contenido de proteína varió entre 183,5 y $259,7 \mathrm{~g} \mathrm{~kg}^{-1}$, Fe desde 68,9 hasta $152,4 \mathrm{mg} \mathrm{kg}^{-1}$, y Zn entre 27,9 y $40,7 \mathrm{mg} \mathrm{kg}^{-1}$. Esta situación podría permitir seleccionar genotipos con alta concentración de estos elementos para mejorar los actuales cultivares. El análisis de correlación simple indicó que el contenido de $\mathrm{N}$ estuvo positivamente correlacionado con el contenido de proteína, $\mathrm{P}, \mathrm{Cu}, \mathrm{Zn}$ y $\mathrm{S}$ y negativamente correlacionado con el contenido de $\mathrm{B}$ y la relación $\mathrm{C} / \mathrm{N}$ de la semilla. $\mathrm{El}$ contenido de $\mathrm{Fe}$ estuvo positivamente correlacionado con el contenido de $\mathrm{Mn}$ y $\mathrm{Ca}$. El contenido de $\mathrm{Zn}$ estuvo positivamente correlacionado con el contenido de N, P, $\mathrm{Cu}$ y $\mathrm{S}$ y negativamente correlacionado con la relación $\mathrm{C} / \mathrm{N}$. No hubo diferencias significativas entre genotipos chilenos con genotipos de otras razas y acervo genético.

Palabras clave: Phaseolus vulgaris, raza Chile, macronutrientes, micronutrientes, colección núcleo. 


\section{LITERATURE CITED}

Anderson, J.W., B.M. Smith, and C.S. Washnock. 1999. Cardiovascular and renal benefits of dry bean and soybean intake. Am. J. Clin. Nutr. 70(suppl.):464S474S.

Aparicio-Fernández, X., T. García-Gasca, G.G. Yousef, M.A. Lila, E. González de Mejía, and G. Loarca-Piña. 2006. Chemopreventive activity of polyphenolics from black Jamapa bean (Phaseolus vulgaris L.) on HeLa and HaCaT cells. J. Agric. Food Chem. 54:2116-2122.

Azevedo, L., J.C. Gomes, P.C. Stringheta, A.M. Gontijo, C.R. Padovani, L.R. Ribeiro, and D.M. Salvatori. 2003. Black bean (Phaseolus vulgaris L.) as protective agent against DNA damage in mice. Food Chem. Toxicol. 41:1671-1676.

Bazzano, L.A., J. He, L.G. Ogden, C. Loria, S. Vapputuri, L. Myers, and P.K. Whelton. 2001. Legume consumption and risk of coronary heart disease in US men and women. Arch. Int. Med. 161:2528.

Becerra-Velásquez, V., and P. Gepts. 1994. RFLP diversity of common bean (Phaseolus vulgaris) in its centres of origin. Genome 37:256-263.

Beebe, S., A.V. González, and J. Rengifo. 2000a. Research on trace minerals in common bean. Food Nutr. Bull. 21:387-391.

Beebe, S.E., J. Rengifo, E. Gaitán, M.C. Duque, F. Pedraza, and J. Nienhuis. 2000b. Structure of genetic diversity among common bean landraces of Middle American origin based on correspondence analysis of RAPD. Crop Sci. 40:264-273.

Beebe, S., O. Toro, A.V. González, M.I. Chacón, and D.G. Debouck. 1997. Wild-weed-crop complexes of common bean (Phaseolus vulgaris L., Fabaceae) in the Andes of Peru and Colombia, and their implications for conservation and breeding. Genet. Resour. Crop Evol. 44:73-91.

Bouis, H.E. 2002. Three criteria for establishing the usefulness of biotechnology for reducing micronutrient malnutrition. Food Nutr. Bull. 23:351-353.

Bressani, R. 2000. Micronutrients policies for agricultural in Latin America. Food Nutr. Bull. 21:538-541.

Díaz-Batalla, L., J.M. Widholm, G.C. Jr. Fahey, E. Castaño-Tostado, and O. Paredes-López. 2006. Chemical components with health implications in wild and cultivated Mexican common bean seeds (Phaseolus vulgaris L.). J. Agric. Food Chem. 54:2045-2052.

Frossard, E., M. Bucher, F. Mächler, A. Mozafar, and R. Hurrell. 2000. Potential for increasing the content and bioavailability of $\mathrm{Fe}, \mathrm{Zn}$, and $\mathrm{Ca}$ in plants for human nutrition. J. Sci. Food. Agric. 80:861-879.
Geil, P.B., and J.W. Anderson. 1994. Nutrition and health implications of dry beans: a review. J. Am. Coll. Nutr. 13:549-558.

Gelin, J.R., S. Forster, S.K. Grafton, P.E. McClean, and G.A. Rojas-Cifuentes. 2007. Analysis of seed zinc and other minerals in a recombinant inbred population of navy bean (Phaseolus vulgaris L.). Crop Sci. 47:1361-1366.

Gepts, P., and D.G. Debouck. 1991. Origin domestication and evolution of the common bean (Phaseolus vulgaris L.). p. 7-53. In van Schoonhoven, A., and O. Voyset (eds.) Common beans: research for crop improvement. Commonwealth Agricultural Bureau, Wallingford, UK.

Ghandilyan, A., D. Vreugdenhil, and M.G.M. Aarts. 2006. Progress in the genetic understanding of plant iron and zinc nutrition. Physiol. Plant. 126:407-417.

Graham, R., D. Senadhira, S. Beebe, C. Iglesias, and I. Monasterio. 1999. Breeding for micronutrientes density in edible portions of staple food crops: Conventional approaches. Field Crops Res. 60:57-80.

Graham, R.D., R.M. Welch, and H.E. Bouis. 2001. Addressing micronutrient malnutrition through enhancing the nutritional quantity of staple foods: principles, perspectives and knowledge gaps. Adv. Agron. 70:77-142.

Guzmán-Maldonado, S.H., J. Acosta-Gallegos, and O. Paredes-López. 2000. Protein and mineral content of a novel collection of wild and weedy common bean (Phaseolus vulgaris L.). J. Sci. Food Agric. 80:1874-1881. Guzmán-Maldonado, S.H., O. Martínez, J.A. Acosta, F. Guevara-Lara, and O. Paredes-López. 2003. Putative quantitative trait loci for physical and chemical components of common bean. Crop Sci. 43:1029-1035.

Hangen, L., and M.R. Bennink. 2002. Consumption of black beans and navy beans (Phaseolus vulgaris) reduced azoxymethane-induced colon cancer in rats. Nutr. Cancer 44:60-65.

Heimler, D., P. Vignolini, M.G. Dini, and A. Romani. 2005. Rapid tests to assess the antioxidant activity of Phaseolus vulgaris L. dry beans. J. Agric. Chem. 53:3053-3056.

Hotz, C., and R. Gibson. 2007. Traditional foodprocessing and preparation practices to enhance the bioavailability of micronutrients in plant-based diets. J. Nutr. 137:1097-1100

House, W.A., R.M. Welch, S. Beebe, and Z. Cheng. 2002. Potential for increasing the amount of bioavailable zinc in dry beans (Phaseolus vulgaris L.) through plant breeding. J. Sci. Food Agric. 83:1452-1457.

Islam, F.M.A., K.E. Basford, C. Jara, R.J. Redden, and S. Beebe. 2002. Seed compositional and disease resistance differences among gene pools in cultivated common bean. Genet. Resour. Crop Evol. 49:285-293. 
Islam, F.M.A., S. Beebe, M. Muñoz, J. Tohme, R.J. Reeden, and K.E. Basford. 2004. Using molecular markers to asses the effect of introgression on quantitative attributes of common bean in the Andean gene pool. Theor. Appl. Genet. 108:243-252.

Khush, G.S. 2002. The promise of biotechnology in addressing current nutritional problems in developing countries. Food Nutr. Bull. 23:354-357.

Meiners, C.R., N.L. Derise, H.C. Lau, M.G. Crews, S.J. Ritchey, and E.W. Murphy. 1976. Proximate composition and yield of raw and cooked mature dry legume. J. Agric. Food. Chem. 24:1122-1126.

Messina, M.L. 1999. Legumes and soybeans: overview of their nutritional profiles and health effects. Am. J. Clin. Nutr. 70(suppl.):439S-450S.

Monsen, E.R. 1988. Iron nutrition and absorption: dietary factors with impact on iron bioavailability. J. Amer. Diet. Assoc. 88:786-791.

Moraghan, J.T., and K.F. Grafton. 1997. Accumulation of Ca in bean cultivars differing in seed size. J. Sci. Food Agric. 74:251-256.

Nestel, P., H.E. Bouis, J.V. Meenakshi, and W. Pfeiffer. 2006. Biofortification of staple food crops. J. Nutr. 136:1064-1067.

Paredes, C.M. 1994. Nuevos antecedentes a considerar en el programa de mejoramiento genético de frejol en Chile. Agric Téc. (Chile) 54:29-41.

Pfeiffer, W.H., and B. McClafferty. 2007. HarvestPlus: Breeding crops for better nutrition. Crop Sci. 47:S-88-S-105.

Rosa, C.O.B, N.M.B. Costa, R.M. Nunes, and P.F.G. Leal. 1998. The cholesterol-lowering effect of black beans (Phaseolus vulgaris L.) in hypocholesterolemic rats. Arch. Latinoam. Nutr. 48:306-310.
Sadzawka, A., M.A. Carrasco, R. Demanet, H. Flores, R. Grez, M.L. Mora, y A. Neaman. 2007. Métodos de análisis de tejidos vegetales. $2^{\mathrm{a}}$ ed. Serie Actas INIA N ${ }^{\circ}$ 40. $140 \mathrm{p}$. Instituto de Investigaciones Agropecuarias, Santiago, Chile.

Sanghvi, T., J. Ross, and H. Heymann. 2007. Why is reducing vitamin and mineral deficiencies critical for development? Food Nutr. Bull. 28 (supl.):S167-S173.

SAS Institute. 2007. SAS/STAT users guide. SAS Institute, Cary, North Carolina, USA.

Shellie-Dessert, K., and F. Bliss. 1991. Genetic improvement of food quality factors. Common beans. p. 649-677. In van Schoonhoven, A., and O. Voyset (eds.) Research for crop improvement. CAB International, CIAT, Redwood Press, Melksham, Wiltshire, UK.

Singh, S.P., P. Gepts, and D.G. Debouck. 1991a. Races of common bean (Phaseolus vulgaris: Fabaceae) Econ. Bot. 45:379-396

Singh, S.P., J.A. Gutiérrez, A. Molina, C. Urrea, and P. Gepts. 1991b. Genetic diversity in cultivated common bean. II. Marker-based analysis of morphological and agronomic traits. Crop Sci. 31:23-29.

Underwood, B.A. 2000. Overcoming micronutrient deficiencies in developing countries: Is there a role for agriculture? Food Nutr. Bull. 21:356-360.

Welch, R.M., and R.D. Graham. 2000. A new paradigm for world agriculture: productive, sustainable, nutritious, healthful food systems. Food Nutr. Bull. 21:361-366.

Welch, R.M., and R.D. Graham. 2004. Breeding for micronutrients in staple food crop from human nutrition perspective. J. Exp. Bot. 55:353-364. 